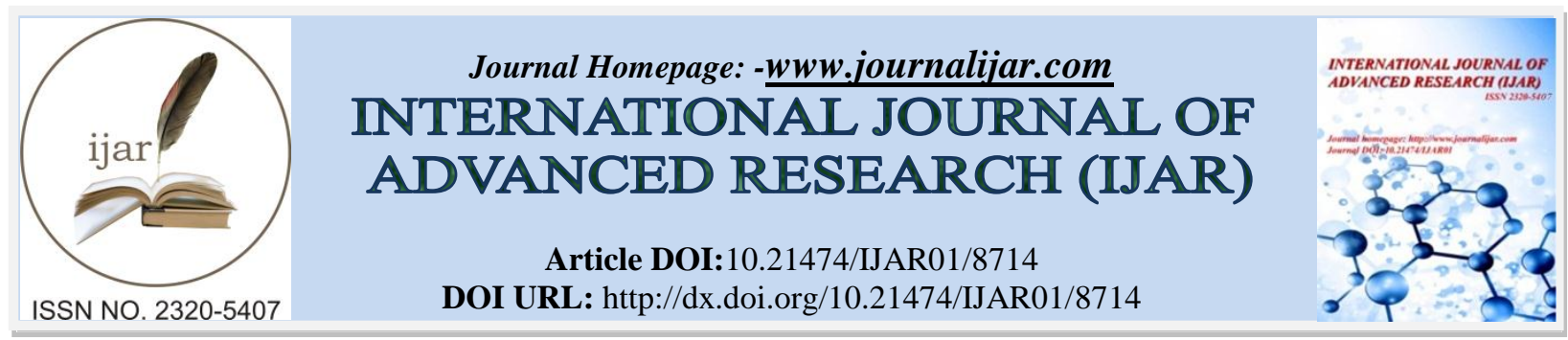

RESEARCH ARTICLE

\title{
A STUDY ON CONSUMER PERCEPTION TOWARDS NANDINI DAIRY PRODUCTS IN CHAMARAJANAGAR DISTRICT OF KARNATAKA.
}

\section{Harish ${ }^{1}$ and Dr. P. Asokan ${ }^{2}$.}

1. Research Scholar,Department of commerce, Bharathiar University, Coimbatore.

2. Associate Professor, Department of Commerce, Thiru.Vi.Ka.Govt.Arts College, Tiruvarur.

\section{Manuscript Info}

Manuscript History

Received: 16 January 2019

Final Accepted: 18 February 2019

Published: March 2019

Key words:-

Indian Dairy Industry, Consumer perception, Global Dairy Industry.

\begin{abstract}
Consumer perception analysis is based on consumer's buying behaviour. It aims at improving business performance through an understanding of the customer's preferences and desires. In today's world of growing competition where there are numerous brands selling the same products, consumers have an abundant number of choices and many diverse factors influence their buying behaviour. The study has been carried out in line of the objectives to find out the awareness level of customers of Nandini dairy product, also to find out their perceptions toward Nandini dairy product with particular emphasis on price and quality and their relationship with demographic characters such as income and gander and to find out the level of satisfaction and attributes performance of milk, ghee, buttermilk and curd in the study area. The study is based on descriptive research and 200 respondents were surveyed with the help of structured questionnaire. Selection of respondents was based on non-probability sampling and purposive sampling technique is used. In the study the statistical tools used are Percentage \& Weighted Average Method.

The findings of the study will be useful for identifying the customers' preferences and need and will pave the way for developing the products which may be most identical to customers' demand.
\end{abstract}

Copy Right, IJAR, 2019,. All rights reserved.

\section{Introduction:-}

Enterprises survive on the market by selling various kinds of products. Therefore,they should pay special attention to their clients. Recognising clients' needs makes it possible to provide them with such products that meet their expectations, bring them satisfaction and are to their liking. The aim of the present study is to show how a typical client behaves on the market of selected dairy products and according to what criteria he chooses the product. Enterprises should get to know the process of making the decision to purchase as well as the factors which affect purchasers' behaviour. It is the client who decides which market offers are the most valuable. It is not important what enterprises think about their own market offer, but what its recipients think about it. Clients' decisions determine the future of an organization.

\section{An Overview Of Indian Dairy Industry:-}

India ranks first in the world in terms of milk production. At present, the dairysector has an estimated consumer demand for milk and milk products at EUR 26 billion, at about 8 percent growth per annum. About 35 percent of 
milk produced in India has meant for processing. The organized sector (large scale dairy plants) processes about 13 million tons annually, while the unorganized sector processes about 22 million tons per annum. Besides, the raw milk production, some of the chief bi-products manufactured like: Infant milk food, malted food, condensed milk and cheese. The southern and western regions collectively contribute for 80 percent of the milk produced in India. The rapid growth of the dairy-processing industry is likely to lead to a greater demand for value-added, milk-based products, such as processed cheese, table butter, sour milk, yoghurt and ice cream.

A higher demand for branded and pro-biotic milk has also led to a rise ininvestment for milk processing. As per Dairy India 2013, the private dairies had outpaced the cooperative sector and become the largest producers of milk in the industry and the Private dairies are contributing double the quantity of milk whencompare to the cooperatives in 2017.

In the development of milk production, dairy cooperatives have a major role.Many small dairy cooperatives are now full-fledged milk producers; Nandini of Karnataka is one of such example. Till about year 2018, India was not on the radar screen of most international dairy companies, since India was neither a major importer nor an exporter of dairy products. Through the 70's, 80's and 90's India used to take some milk powder and butter oil as aid. Exports from India were insignificantly small. From 2000 onwards, Indian dairy products, particularlymilk powder, and ghee started making their presence felt in global markets.

Nevertheless, the Indian dairy sector has started as the producer-owned andprofessionally-managed cooperative system. As of March 2017, India's 96,000 local dairy cooperative societies (DCS) included more than ten million farmers have integrated in a three-tiered cooperative structure. Though dairy cooperatives have found throughout India, the cooperative movement has been most successful in a few states, notably Gujarat. Gujarat's success can be attributed to a higher rate of farmer activism and more efficient political institutions. Over the years, states have developed popular dairy brands such as Amul (from Gujarat), Vijaya(from Andhra Pradesh), Verka (from Punjab), Saras (from Rajasthan), Nandini(from Karnataka), Milma (from Kerala) and Gokul (from Maharashtra). These brands have earned high degrees of brand recognition and customer confidence, especially within in their respective states. The Indian dairy industry faces challenges from the international dairy market. The Indian dairy industry had characterized by relatively high costs in milk production, processing, and marketing, and relatively poor quality of milk due to unhygienic handling, this could potentially pose a significant threat to the industry and its farmers.

\section{The Global Dairy Industry:-}

Dairy companies all over the world face a number of changes and challengeswhich are forcing them to reconsider their strategies. The most importantchallenges are a growing demand for dairy products, with world demand growing by 2 percent a year or a quantity equal to the entire annual production of Australia, coupled with concerns about the milk supply growing at a slower pace than demand.

Furthermore, dairy companies face an increasing number of consumerrequirements in combination with increasing customer power. Food retailers, the foodservice industry and the food processing industry are the key customers for dairy products. The leading companies in this sector tend to be significantly larger than the players in the dairy industry and the on-going global consolidation process is further increasing their market power. Consequently, the concentration process by means of mergers, acquisitions and strategic alliances in the dairy industry has been very pronounced and is expected to continue. The milk and dairy products have a prominent place in the global food products market. Due to factors like rising concerns about vegetarianism, health advantages of milk and dairy products over non-vegetarian foods, andecological balance, the use of milk and dairy products is increasing globally.

This has resulted in increased worldwide production of milk. As demand in dairy products is not rising at equal rates all over the world buthardly at all in developed and strongly in some developing regions the challenges dairy companies face vary depending on the market they operate in. Companies operating in the big but mature dairy markets of Europe and the US face limited market growth opportunities in volume terms as per capitaconsumption levels are among the highest in the world and growth can only occur by increasing market shares or switching to higher value-added products.

Due to these limited market opportunities in developed countries, multinationaldairy companies are often attracted by strong growth markets in developing countries. To benefit from the growth of their own domestic markets, local companies will have to raise product quality and efficiency to be able to withstand foreign competition. 


\section{Consumer Perception:-}

Consumer perception is a behaviour of human responses to the product andmarketing. The study of consumer perception focuses on how individualsmake their decisions to spend available resources. Basically it's a study regarding WHAT to buy? How to buy? And WHAT is the criteria behind consuming a particular product? Thus a consumer's perception can be defined as a heightened state of awareness that motivates consumer to seek out, attend to and think about the product's information prior to purchase. The production and marketing of dairy food products has caused many concerns, particularly from an increasingly discriminating consumer. Today's consumers are placing increasing importance on food quality, food safety and environmental quality more than ever.

\section{Objectives Of The Study:-}

1. To find out the awareness level of customers of Nandini dairy products in the study area.

2. To find out perceptions of people towards Nandini dairy product with particular emphasis on price and quality and their relationship withdemographic characters such as income and gander.

3. To find out the level of satisfaction and performance of different attributes of milk, ghee, buttermilk and curd in the study area.

\section{Research Methodology:-}

The project entitled "A study on consumer perceptions towards Nandinidairy products in Chamarajanagar district of Karnataka" was started from $1{ }^{\text {st }}$ February 2014. The specific objectives of the study were to study the purchasepattern adopted by customers and factors influencing purchase in study area, alsoto find out criticality of some major attributes responsible for satisfactoryperformance and overall performance of buttermilk, ghee and curd in study area.Also to find out the efficiency of feedback mechanism adopted by dairy in thestudy area.

\section{Sources Of Data:-}

Primary as well as secondary data were collected to meet the objectives of the study.

\section{Primary Data:-}

Primary data was collected with the help of personal interviews and structured questionnaire.

\section{Secondary Data:-}

Secondary data was collected from different journals, review papers and related websites.

\section{Research Design: -}

Descriptive Research:-

This part describes the methods and procedures used for collection and analysisof data in the study. The specific methodology adopted for the selection of different units and other details are given below

\section{Survey Approach:-}

\section{Sample Survey}

\section{Sampling Method:-}

Non Probability

\section{Sampling Technique:-}

Purposive sampling

\section{Sample Unit:-}

household (The person who made decision regarding purchase of dairy products.)

\section{Sample Size:-}

200

Sampling Area:-

\begin{tabular}{|c|c|}
\hline Chamrajnagar & 50 \\
\hline Gundulpet & 50 \\
\hline
\end{tabular}




\begin{tabular}{|c|c|}
\hline Kollegala & 50 \\
\hline Nanjanagudu & 50 \\
\hline
\end{tabular}

\section{Research Instrument:-}

Considering the nature of study as well as for theobtaining correct information from the respondents, it was decided to collectinformation through structured questionnaire prepared with the help of available related literature and research reports.

\section{Analytical Tools:-}

Mainly tabular analysis and graphical presentation and used statistical tools to achieve the stipulated objective of the study.

\section{Limitations Of The Study:-}

1. Respondents may have given biased or false information.

2. Analysis is purely based on the responses of the respondents.

\section{Area Of Respondents:-}

The area, of the study is given by the host organization. The organization wantedto open new outlets in above selected areas. The above graph indicates that outof 200 samples, each 4 blocks had 50 respondents. i.e.-25\%.

Table 1:-Age of respondents

\begin{tabular}{|c|c|c|}
\hline \multicolumn{1}{|c|}{ Age group } & Frequency & Percentage (\%) \\
\hline $10-25$ & 44 & 22.0 \\
\hline $26-40$ & 88 & 44.0 \\
\hline $41-55$ & 68 & 34.0 \\
\hline & 200 & 100.0 \\
\hline
\end{tabular}

Age groups were categorised in 4 main categories viz. 10-25 years, 26-40 years,41-55 years and more than 55 years. $44 \%$ of the respondents belonged to agegroup of 26-40 years, 34\% belonged to age group of $41-55$ years and $22 \%$ respondents belonged to age group of 10-25 years.

No respondent had age more than 55 years.

Table 2:-Gender

\begin{tabular}{|c|c|c|}
\hline Gender & Frequency & Percentage $(\%)$ \\
\hline Male & 80 & 40.0 \\
\hline Female & 120 & 60.0 \\
\hline 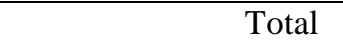 & 200 & 100.0 \\
\hline
\end{tabular}

Considering the gender composition of respondents the female respondents havedominated in numbers, as $60 \%$ of respondents are female because sampling unitof the survey was household, however male respondents were also given prominence as they have the decision making authority for the purchase of dairy products.

Female respondents happened to be at right place at right time during household survey so they have comparatively larger share.

Table 3:-Level of Education

\begin{tabular}{|l|c|c|}
\hline \multicolumn{1}{|c|}{ Education Level } & Frequency & Percentage (\%) \\
\hline 12 and below & 40 & 20.0 \\
\hline Graduate & 72 & 36.0 \\
\hline Post graduate & 24 & 12.0 \\
\hline Diploma ITI & 36 & 18.0 \\
\hline Certificate course & 28 & 14.0 \\
\hline \multicolumn{1}{|c|}{ Total } & 200 & 100.0 \\
\hline
\end{tabular}


Above table illustrates that education level of the respondents. As can be seenfrom the table $36 \%$ attained graduation, $20 \%$ got below 12 th education, $18 \%$ had diploma, and $14 \%$ had done certificate courses. Only $12 \%$ of the respondents attained post-graduation. The level of education is considered as one of the important factors in making decisions and choosing the products, as there may be a significant impact ofeducation on satisfaction level of consumers.

Table 4:-Occupation

\begin{tabular}{|l|c|c|}
\hline \multicolumn{1}{|c|}{ Occupation } & Frequency & Percentage $(\%)$ \\
\hline Businessman & 60 & 30.0 \\
\hline Service in private sector & 56 & 28.0 \\
\hline Service in government sector & 48 & 24.0 \\
\hline Housewife & 36 & 18.0 \\
\hline \multicolumn{1}{|c|}{ Total } & 200 & 100.0 \\
\hline
\end{tabular}

Considering the profile of study area of Chamarajanagar district, occupations ofrespondents were categorised into 5 major groups of businessman, service inprivate sector, service in government sector, housewife and others.

Table 5:-Annual Income

\begin{tabular}{|l|c|c|}
\hline Income Group & Frequency & Percentage (\%) \\
\hline Up to 2 lakh & 20 & 30.0 \\
\hline $200000-299999$ & 60 & 48.0 \\
\hline $300000-399999$ & 96 & 12.0 \\
\hline 400000 above & 24 & 100.0 \\
\hline Total & 200 & \\
\hline
\end{tabular}

Considering the area profile of respondents the income group were classified into4 main categories viz. Rs.100000199999, Rs.200000- 299999, Rs.300000- 399999 and above Rs.400000.

Of 200 respondents, 48\% were having annual income of 300000-399999, 30\%were earning between 200000299999 annually, $12 \%$ belonged to income class of above 400000 and $10 \%$ of respondents were having income below 2 lakhs.

Income is a demographic representation, it may have a bearing on the perceptionsof individuals towards dairy products. Majority of the respondent were seen to be in the fairly good income group compared to may backward areas.

Table 6:-Aware of Nandinidairy products

\begin{tabular}{|c|c|c|}
\hline Awareness & Frequency & Percentage (\%) \\
\hline Yes & 192 & 96.0 \\
\hline No & 8 & 4.0 \\
\hline Total & 200 & 100.0 \\
\hline
\end{tabular}

The above table shows that the awareness of Nandinidairy products amongrespondents is quite high as almost $96 \%$ of 200 respondents have heard about NandiniDairy and its products. Only 4\% of respondents have said no, and indicated that they are not aware of Nandini dairy or its products.

Table 7:-Purchase of Nandinidairy products

\begin{tabular}{|c|c|c|}
\hline Purchase & Frequency & Percentage $(\%)$ \\
\hline Yes & 168 & 84.0 \\
\hline No & 32 & 16.0 \\
\hline Total & 200 & 100.0 \\
\hline
\end{tabular}

Respondents were asked the question whether they have purchased any of theproducts of Nandini dairy and the same is presented in table 4.7 some $84 \%$ of respondents who were aware of products have purchased it. Only $16 \%$ 
ofrespondents have indicated that they did not purchase Nandini dairy products. The above graph is indicating that Nandini diary has penetrated its products well in the study area.

Table 8:-Purchased products

\begin{tabular}{|l|c|c|c|c|c|}
\hline \multicolumn{1}{|c|}{ Purchase } & Yes & Percentage & No & Percentage & Total \\
\hline Milk & 160 & 80.0 & 40 & 20 & 200 \\
\hline Ghee & 152 & 76.0 & 48 & 24 & 200 \\
\hline Buttermilk & 148 & 74. & 52 & 26 & 200 \\
\hline Curd & 144 & 72.0 & 56 & 28 & 200 \\
\hline
\end{tabular}

Above table is based on the responses of respondents after they were asked thequestion, what products they have purchased among milk, ghee, buttermilk and curd. And the graph shows that maximum respondents have purchased milk as almost $80 \%$ of respondents said yes to milk purchase, followed by ghee which was purchased by $76 \%$ of respondents buttermilk purchased by $74 \%$ and curd purchased by almost $72 \%$ of respondents.

The above table is the depiction of multiple answering by respondents as maximum respondents have answered yes to more than one product.

Table 9:-Opinion about Nandini dairy products price

\begin{tabular}{|c|c|c|}
\hline Opinion on Price & Frequency & Percent \\
\hline Costly & 104 & 52.0 \\
\hline Very costly & 40 & 20.0 \\
\hline Average Total & 24 & 12.0 \\
\hline \multicolumn{2}{|c|}{ Tre } \\
\hline
\end{tabular}

Above table represents the opinions of respondents on prices of Nandini dairyproducts the respondents were asked to answer on whether they think that prices of products with respect to other available option in market are cheaper, at par/ average, costly and very costly. Above $62 \%$ of respondents were of the opinion that products were bit costly, only $24 \%$ of respondents said that the products were very costly and only $14 \%$ respondents said that prices of products were average/ at par of market rate.

The table indicates that people mostly thinks that the products of Nandinidairy are costly which need to be addressed by the competent authority in a waythat overall business profitability of the organization is not affected adversely.

\section{Summary and Conclusion:-}

The project entitled "The study on consumer perceptions towards Nandinidairy products in Chamarajanagar district of Gujarat state" was carried out to know the customers' perceptions for dairy products. Based on the finding of the study it can be summarized that the awareness of Nandini dairy products among respondents is quite high as almost $96 \%$ of the respondents knew about NandiniDairy and its products. About $84 \%$ of respondents who were aware of products have also purchased it. Maximum respondents have purchased milk (80\%) followed by ghee (76\%) buttermilk $(74 \%)$ and curd $(72 \%)$.

Respondents felt that prices of products of Nandini dairy with respect to otheravailable option in market were somewhat costlier as $62 \%$ of respondents were of the opinion that products were bit costly, also $24 \%$ of respondents said that the products were very costly and only $14 \%$ respondents said that prices of products were average or at par of market rate. As regards gender influence there is slight difference of opinions of male and female on prices of Nandini dairy products.

Mostly people were satisfied with quality of products as some $43 \%$ ofrespondents were of the opinion that products were of excellent quality, $41 \%$ of respondents felt that Nandini dairy products were of good quality. Only $15 \%$ of respondents said that Nandini dairy products were of average quality. And there is no or slight bearing of gender on perception of quality of Nandinidairy products. The improvement in income level of respondents the perceptions towards quality of Nandini dairy products changes and less number of respondents of higher income group rated lower as compared to the respondents of lower income groups. 
The findings of the study revealed that almost all respondents in the study weresatisfied with the products. More specifically about $50 \%$ of respondents were $80 \%$ satisfied with products and about $29 \%$ of respondents were $70 \%$ satisfied and $21 \%$ said that they were $90 \%$ satisfied. Also with the improvement in incomelevel of respondents the level of satisfaction improved.

For milk, ghee, buttermilk and curd the most important and best performingfactors were taste and nutritious value as per the responses given by the respondents and the mean value comparison of all factors which included Thickness, Smell, Availability, Packaging, Texture, Nutritious value and Taste.

In ghee the durability factor was considered by the respondents and about 50\% of the respondents who have purchased ghee said that durability of ghee wasgood, $36 \%$ of respondents felt that durability was average and $14 \%$ of respondents said that the durability was very good.

\section{Conclusion:-}

With ever increasing competition in dairy industry it become imperative tounderstand the preferences and perceptions of customers. Based on the findings, it may be inferred that Nandini dairy has worked well to make people aware about its products in the study area and it is very well proven through the findings. Also despite the availability of other dairy brands in market, large no of people are purchasing its products as almost all major products i.e. milk, buttermilk and ghee found to be purchased by respondents $(>70 \%)$.

Quality and prices build the value of brand. As far as the prices alone areconcerned, respondents think that prices of Nandini dairy products are somewhat higher however the quality is rated as good by maximum respondents. Also quality has got more importance by respondents when choosing the particular brand, hence most people are purchasing its products. Both male and female respondents have same opinion on quality but people of different income group have different opinions for it.

Satisfaction is the utmost important element, required to sustain long in marketin any industry, and satisfaction level of sample customers is considerably high and no respondent was unhappy or dissatisfied with the offerings of Nandinidairy.

Maximum respondents were in the awe of taste and nutritious value ofNandini dairy products, while other attributes like availability, packaging, thickness, smell and texture were also performing well.

The findings of the study will be useful for identifying the customers' preferencesand need and will pave the way for developing the products which may be most identical to customers' demand.

\section{References:-}

1. D. Ashok, AbhayPrakashSriwastwa (2012), Product Innovation And ItsInfluence on Consumer Purchasing Pattern - a study on packageddairy products in Bettiah: IOSR Journal of Business and Management (IOSRJBM) ISSN: 2278-487X Volume 1 , Issue 1 (May-June 2012), PP 22-28.

2. Government of India, Ministry of Agriculture, Annual Report 2012- 13,,Department of Animal Husbandry, Dairying and Fisheries.

3. GilaninialShahram; MohmmadTaleghani, Mohammad Reza KhorshidiTalemi (2013). "Investigating the Impact of Service Quality in DistributionSystem on Customer Satisfaction" Singaporean Journal Of Business Economics, and Management Studies Vol.2, no.1, 2013.

4. Gupta, Arpita (2011), Report on Identifying Factors Behind Decreasing MarketShare and Study of Consumer Behavior: PGDM report.

5. Gupta, KritiBardhan (2009), Consumer Behavior for Food Products in India:19 Annual World Symposium, International Food \& Agribusiness Management Association report.

6. National Dairy Development Board Annual report, 2011-12. 
7. Nieurawski, Lech (2006), Determinants of Customer Satisfaction on the Markets of Selected Dairy Products: Polish Journal of Food andNutrition Sciences; 2006 , Vol. 15/56, SI 1, pp. 155-160.

8. Parekh, J. V. (2006), "Milky Ways", Times Food Processing Journal, Oct. - Nov. Prasad, M. V. Rama (2006), "Dairy Products: Consumer Preferences - A Limited Survey of Vishakhapatnam", Journal of Marketing \&Communication, Vol. 2, Iss. 2, Sep. - Dec., pp. 63-71.

9. Sharma and Prabhakar. (2000). "Marketing of Milk- An Opinion Survey of Consumer Perceptions, Rajahmundry, AP”. Indian Journal of Marketing, VolPp: 10-13.

10. Singh, R. (2011), India Dairy and Products Annual Report 2010. 